\title{
IAMJ
}

INTERNATIONAL

AYURVEDIC

MEDICAL JOURNAL

ISSN: 2320-5091

Impact Factor: 6.719

Review Article

\section{SIGNIFICANCE OF SHARIR RACHANA (ANATOMY) IN POSITION OF GIVING BASTI AND NASYA}

\section{Jyoti Gangwal $^{1}$, Sanjay Kholiya ${ }^{2}$}

Assistant Professor ${ }^{1}$, Dept. of Sharir Rachana, Jayoti Vidyapeeth Women's University, Jaipur, Rajasthan, India ${ }^{2}$ PG Scholar, Dept. of RSBK, National institute of Ayurveda, Jaipur, Rajasthan, India

Corresponding Author: jyotigangwal4799@gmail.com

https://doi.org/10.46607/iamj1508122020

(Published online: December 2020)

Open Access

(C) International Ayurvedic Medical Journal, India 2020

Article Received: 04/11/2020 - Peer Reviewed: 18/11/2020 - Accepted for Publication: 19/11/2020

\section{Check for updates}

\begin{abstract}
Ayurveda, the science of life which deals with the maintenance of physical, mental and spiritual well-being of an individual has its origin thousands of years ago from Vedic period. Among the four Vedas, Atharva Veda contributes more to Ayurveda. Ayurveda is also considered as fifth Veda or Upaveda. Ayurveda is divided into eight main branches for the convenience in clinical practice. They are Shalya Tantra, Shalakya Tantra, Kaya Chikitsa, Kumarabritya, Bhuta Vidhya, Agada Tantra, Rasayana and Vajikarana Tantra. In Kaya Chikitsa there are some therapeutic procedures included which was mentioned by ancient Acharya. They are five in number. Nowadays these procedures have their separate branch, known as PanchaKarma. Present article only based on position of giving Basti and Nasya. Correct position during these procedures helps in benefits of therapy. According to Acharya Charak Vaman, Virechana, Niruha Basti (Asthapana Basti), Anuvasana Basti, Nasya are the five procedures of PanchaKarma. He mentioned further types of Basti and Nasya in Chikitsa Sthan.
\end{abstract}

Keywords: Ayurveda, PanchaKarma, Position, Vaman, Chikitsa Sthan. 


\section{INTRODUCTION}

In Ayurveda Acharya Charak, Sushruta, Vagbhatta have described about the position giving therapeutic procedures like Basti and Nasya. Both the procedures are including in Pancha Shodhana Karma or PanchaKarma. There was different-different Karma mentioned in Brihatrayi. According to Acharya Charak Vaman, Virechana, Niruha Basti (Asthapana Basti), Anuvasana Basti, Nasya are the five procedures of PanchaKarma. He mentioned further types of Basti and Nasya in Chikitsa Sthan. There are five types of Nasya- Navana, Avapida, Dhmapana, Dhooma, Pratimarsha. There are three types of Basti-Anuvasana Basti, Niruha Basti (Asthapana Basti), Uttar Basti. Acharya Sushruta merges both Niruha and Anuvasana as one so called as Basti. Because of importance of blood from surgical point of view he included Raktamokshan or bloodletting in PanchaKarma. So, according to Acharya Sushruta the procedures were as follows- Vamana, Virechana, Basti, Nasya, Raktamokshan. Further, there are two types of BastiNiruhika and Snehika Basti. The former Niruhika also called Asthapana Basti or Matra Basti and Snehika also named as Anuvasana Basti or Madhutailika Basti or Yuktaratha Basti or Siddha Basti. Anuvasana Basti is unctuous formulation and Asthapana Basti is nonunctuous. Acharya Sushruta has mentioned two types of Nasya in Chikitsa Sthan. They are Shirovirechana and Snehana. Again, Shirovirechana and Snehana have two types. Shirovirechana has divided into Avapida and Pradhamana and Snehana has divided into Nasya and Pratimarsha. Acharya Vagbhatta has mentioned Basti, Vamana, Kayavirechana, Shirovirechana and Raktavisrutti or Raktamokshan in PanchaKarma. Here form Basti, Acharya considered Asthapana Basti. Vagbhatta not included Anuvasana in PanchaKarma. Acharya Vagbhatta has mentioned three types of Basti-Anuvasana Basti, Niruha Basti (Asthapana Basti), Uttar Basti same as Acharya Charak. According to Vagbhatta Nasya is divided into three types-Virechana, Baranahan and Shamana.

\section{- Position for giving Basti (Drug administration through anal canal) \\ * Position for giving Niruha Basti-}

\section{According to Charak-}

- While the patient lies on Vaam Parshva position, Grahani and Guda are situated on left side, the administering solution reaches easily, and the folds also disappear. Hence Basti should be administered to the patient in Vaam Parshva position. (Ca.Si.3/24-25)

\section{According to Vagbhatta-}

- The person should lie neither too high nor too low, in Vaam Parshva position folding his right thigh at knee joint and extending the left thigh.

(A.H.Su.19/23-24)

\section{According to Sushruta-}

- The Niruha Basti should be administered to those persons who have already taken the Sneha Basti. The patient should be massaged well with oil and treated with sudation therapy; his bowel and bladder should be cleared. The room should be free from direct approach of wind and the Basti should be applied at noon. The patient should be in Vaam Parshva position on a wide bed which should be well provided with supports at the lower end, wide and rose at the pelvic region.

- The patient should keep his right thigh flexed at knee joint and left one extended. He should be relaxed and calm and taken his food 3-4 hours before procedure; should not be talking and should keep the body fully relaxed. After the procedure, the patient should be asked to get up after waiting for thirty Matras from the time of application of Basti. In order to help Basti fluid to come out the patient should be asked to sit in the squatting posture. The medicated enema takes a Muhurta to come out completely. (Su.Ci.38/3-4)

* Position for giving Basti in Garbhini(Pregnant women)

\section{According to Charak-}

- If constipation occurring due to Udavarta during eighth month of pregnancy, is not relieved either by use of Anuvasana Basti (uncting enema) or else with unctuous edibles mixed with substances capable of suppressing Vata along with uncting enema with the oil prepared with Madhuka, then it 
should be considered as incurable by this procedure and Niruha Basti (evacuation enema) prepared with drugs should be used. To a pregnant woman cleansing and uncting enema should be given keeping her in Nyubjavastha. (Ca.sha.8/29)

\section{* Position for Uttar Basti (Douche) in females} According to Charak-

- In case of female, the length of catheter should be ten Angula, with circumference similar to that of urethral canal in which the Mudga (green gram) may pass on. In genital tract, it should be inserted up to four Angula while in urethra up to two Angula and one Angula in female child and parallel to vertebral column. (Ca.Si.9/64-70)

The catheter should be inserted while she is lying in supine position, flexing her legs at knee joints. Thus, the unction should be given through douche twice, thrice or four times in twenty-four hours. After the douche is given, suppository somewhat thicker should be inserted. In this way, the treatment should be continued for three days gradually increasing the dose of uncting substance. This should be repeated after three days in the same manner.

\section{According to Vagbhatta-}

- The douche should be administered to the woman, who is lying in supine position with her legs folded at the knee joints, three to four times in a day and night. (A.H.Su.19/81)

* Position for giving Nasya (Nasal drug administration)

\section{According to Sushruta-}

- The person, to whom head cleansing errhines are to be administered, should clear his bowel and bladder and should not be on empty stomach. The appropriate period for the Nasya is when the weather is normal. The person should clean his mouth and nasal passage by inhaling medicated fumes. His neck, cheeks and forehead should be mild fomented by the warmth of the palms. The room should be free from the direct approach of wind, sun rays and dust. The patient should lie supine with his hands and legs relaxed and the neck slightly extended. His eyes should be cov- ered with a cloth and the physician should lift up the tip of the nose by the index finger of his left hand and administer the medicated oil into the cleansed nostrils of the patient with his right hand through an oyster shell or a cotton plug. The Sneha should be kept in a golden, silver, copper, Mani or an earthen pot or an oyster shell and warmed by hot water. This Sneha should be instilled in lukewarm state in an uninterrupted stream without undue haste so that it does not spill into the eyes. (Su.Ci.40/25)

\section{According to Charak-}

The physician should administer the saturating unction into the nostrils of the person who has finished routine duties and lying in supine position comfortably on a cot which is well covered with slightly extended neck and raised feet. If the neck is not extended than the nasal drug does not reach to the head while on the other hand if it is too extended, then the medicine which is administered will remain in the brain. Hence one should foment the head of the person lying in such position for proper evacuation. After fomenting, the nose should be raised up with the left thumb and with the right hand one should administer the nasal unction methodically with tube or tampon equally in both nostrils. Thereafter it should be fomented and the uncting substance with mucous should be drawn out frequently so that it does not stay. (Ca.Si.9/98104)

\section{According to Vagbhatta-}

- The person should be made to lie in supine position with extending his arms and legs, the legs slightly raised and the head slightly lowered. (A.H.Su.20/18)

\section{DISCUSSION}

\section{* Position for Basti (Drug administration through anal canal)}

In Ayurveda text there is vast description to use anal canal as a route of drug administration. Their main aim was to deliver the drug into the sigmoid colon. To use this route, one should have the knowledge of the anatomy of lower gastro-intestinal tract. Acharya described various anatomical positions for administra- 
tion of drug according to the clinical condition of patient and the mechanism of drug. Like-

* Vaam Parshva (left lateral) - In Ayurveda, the position for administering Basti was mentioned as Vaam Parshva. Vaam means left and Parshva means lateral; it means left lateral position. In modern science, there is description of many positions for giving drug through anal canal like left lateral position, knee chest position, lying $\$$ bod position but the left lateral position or the sims positions is the most commonly used position. This position is similar to the position as described in Ayurveda for giving Basti. This position facilitates the flow of solution easily into the sigmoid and descending colon, which are on the left side. Having the right leg acutely flexed provides adequate exposure of the anus.

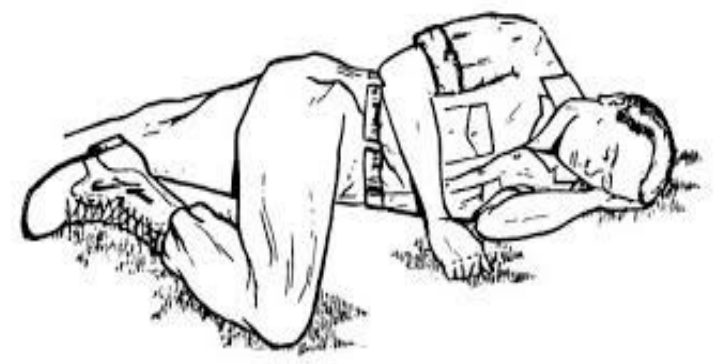

Figure 1: Left lateral position

Nyubjavastha (knee chest position) - According to Charak, this position is mentioned for Garbhini (pregnant lady) for giving Basti in $8^{\text {th }}$ month. This position represents the knee- chest position of modern science. In the $8^{\text {th }}$ month of pregnancy, the uterus is enlarged to such extent that it compresses the sigmoid colon. If the enema is given in left lateral position in this condition, the drug will not reach to the sigmoid colon. So, the enema is given in knee chest position in pregnancy. In this position the uterus moves towards the anterior abdominal wall and the pressure is released from the sigmoid colon.

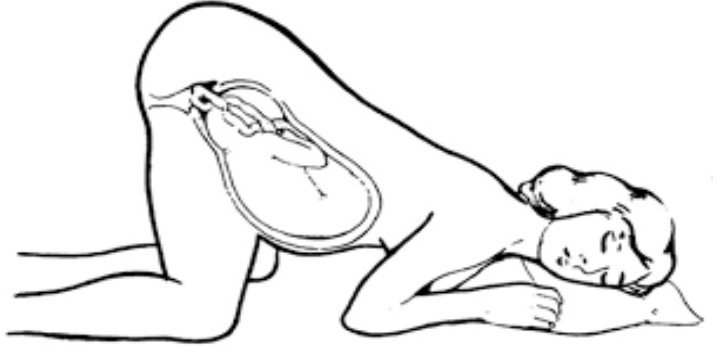

Figure 2: Knee chest position

\section{n for Uttar Basti (Douche) in females}

* Uttanavastha - This position is described for giving Uttar Basti in females. Our Acharya knew that in females there may be additional route of drug administration; that is vagina and urethra. For giving douche through this route the position mentioned in Ayurveda is somewhat similar to lithotomy/dorsal recumbent position described in modern science.

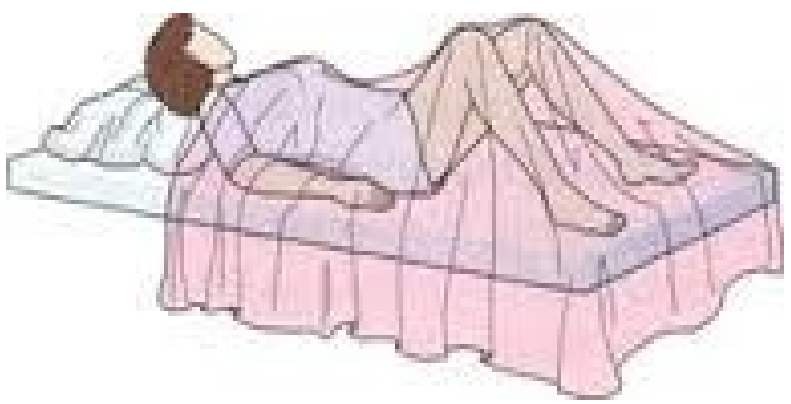

Figure 3: Dorsal recumbent position

The reason to administer drugs through the anal canal is that this area has two properties that make it excellent drug delivery system: it is moist, and this region has an excellent blood supply. This means drugs will be absorbed into the bloodstream and reach in circulation very quickly - often more quickly than any route of drug administration.

\section{* Position for giving Nasya (Nasal drug admin- istration)}

The nose is considered as a route of drug administration for systemic drug delivery, especially when rapid absorption and effect are deserved. Many positions are mentioned in modern science for administration of nasal drugs. These are head upright (HUR), lateral head-low position (LHL), head down and forward (HDF) and lying head back position (LHB). Among these positions, LHB position is preferred for nasal 
administration. Lying down in supine position with the head in hyperextension, so that the chin is the highest point of the head is LHB position.

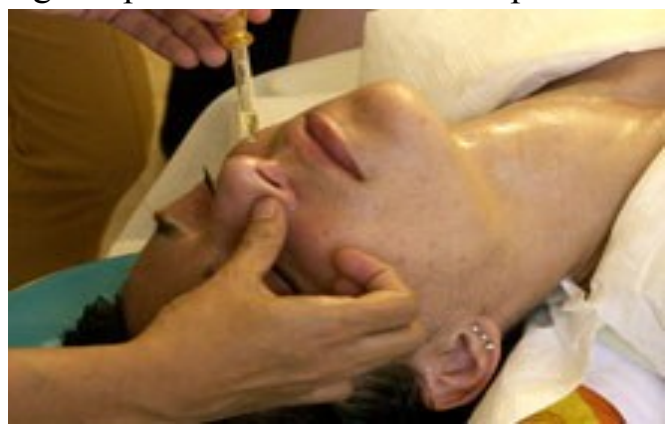

Figure 4: Position for Nasya

It is also known as proetz or mygind position. This is preferred because in this position the target region like pharynx (oropharynx, nasopharynx), internal nares, ethmoid, frontal and sphenoid sinuses are easily approached. The nasally administered medication contacts the olfactory mucosa. The olfactory mucosa is located in the upper nasal cavity just below the cribriform plate of the skull. It contains olfactory cells which traverse the cribriform plate and extend up into the cranial cavity. When medication molecules come in contact with this specialized mucosa they are rapidly transported directly into the brain, skipping the blood-brain barrier and achieving very rapid cerebrospinal fluid levels. This concept of transfer of molecules from the nose to the brain is referred to as the nose-brain pathway. Administering medications via the nasal mucosal offers several advantages:

1. Here the drug molecule is transferred quickly across the single epithelial cell layer directly to the systemic blood circulation without first-pass hepatic and intestinal metabolism.

2. The rich vascular plexus of the nasal cavity provides a direct route into the blood stream for medications that easily cross mucous membranes.

3. Easy, convenient and safe method of drug administration.

$>$ Similar to modern science, in Ayurveda, for giving Nasya the person is said to lie in supine position with slightly extended neck which resemble to LHB position. It means our Acharya knew that nose can be used as route for drug administration and they also knew that it works more rapidly and efficiently so they recommended it in emergency conditions too. They were also known about the anatomy of nose and position of person for nasal drug administration so it can be work most effectively.

\section{CONCLUSION}

Acharya Charak, Sushruta and Vagbhatta have mentioned anatomical positions for Nasya and Basti procedures. It shows that they were well known about different routes of drug administration. The positions for different procedures like Nasya, Basti etc. mentioned in Ayurveda is followed by modern science in nowadays.

\section{REFERENCES}

1. Ashtanag Hridayam English Translation, Sutra Sthana And Sharir Sthana, By Prof. K. R. Srikantha Murthy, Vol. 1 Krishnadas Academy, Varanasi, Edition 1994.

2. Ayurvedic Prasuti Tantra Evam Stri Roga, Premvati Tiwari, Part 1, Edition 1999, Ckaukhambha Orientalia, Varanasi.

3. Charaka Samhita English Translation By Prof. Priyavrat Sharma Vol. 2 Cikitsa Sthana To Siddhi Sthana, Chaukhambha Orientalia, Varanasi.

4. Charaka Samhita English Translation By Prof. Priyavrat Sharma Vol. 1 Sutra Sthana To Indriya Sthana, Chaukhambha Orientalia, Varanasi.

5. Charaka Samhita With Vidyotini Hindi Commentary By Pt. Kashinath Shastri \& Dr. Gorakhanatha Chaturvedi, Part-1\&2, Published By Chaukhambha Bharati Academy Varanasi, 22nd Edition 1996.

6. Charaka Samhita English Translation By Dr. Ram Karan Sharma And Vaidya Bhagwan Dash, Vol.2 Nidana Sthana To Indriya Sthana, Chaukhambha Sanskrit Series Office, Varanasi, 1996.

7. Charaka Samhita English Translation By Dr. Ram Karan Sharma And Vaidya Bhagwan Dash, Vol.6 Kalpa Sthana And Siddhi Sthana, Chaukhambha Sanskrit Series Office, Varanasi, 1996.

8. Charaka Samhita English Translation By Dr. Ram Karan Sharma And Vaidya Bhagwan Dash, Sharir Sthana, Chaukhambha Sanskrit Series Office, Varanasi, 1996.

9. Sushruta Samhita English Translation By Prof. K. R. Shrikantha Murthy, Vol.2 Chikitsa Sthana, Chaukhambha Orientalia, Varanasi. 
10. Sushruta Samhita Of Sushruta With Ayurveda Tatva Sandipika Hindi Commentary By Kaviraja Ambika Dutta Shastri, Chaukhambha Sanskrit Sansthan Varanasi, Part 19th Edition 1995.

11. Textbook of Obstetrics-D. C. Dutta, $7^{\text {th }}$ Edition, New Central Book Agency Ltd., London.

12. Www.Wikipedia.Org.

\section{Source of Support: Nil}

\section{Conflict of Interest: None Declared}

How to cite this URL: Jyoti Gangwal \& Sanjay Kholiya: Significance Of Sharir Rachana (Anatomy) In Position Of Giving Basti And Nasya. International Ayurvedic Medical Journal \{online\} 2020 \{cited December, 2020\} Available from:

http://www.iamj.in/posts/images/upload/5299 5304.pdf 